\title{
New Sales and Contract Law in Argentina and France
}

\author{
Models for Reform Inspired by the CISG and the PICC?*
}

Edgardo Muñoz \& Inés Morfín Kroepfly*

\begin{abstract}
The Argentine and the French civil codes have recently undergone substantial modifications to their contract law provisions. These novel statutes could serve as models for future B2B contract law reforms in Latin American jurisdictions and beyond, as former Argentine and French laws have done in the past. The authors offer a contribution that paves the way in that direction with a systematic comparative analysis. As a starting point, this article unveils the influence that the modern unified laws on contracts (UNIDROIT Principles on International Commercial Contracts (PICC) and United Nations Convention on Contracts for the International Sale of Goods of 1980 (CISG)) have in Argentina's and France's new contract law. It also highlights the most obvious similarities and differences in both sets of rules. This contribution goes beyond simple tertium comparisons; the authors analyse which of the two laws offers better, or more effective, rules to achieve the desired contract law functions in various matters. Readers are provided with the best rule or solution to address the problem in question and, as the authors hope, they should conclude that both models provide for a range of complementary solutions for modern contract law reforms.
\end{abstract}

Keywords: contracts, sales, law reform, CISG, UNIDROIT Principles, Argentina, France, comparative law.

\section{A Introduction}

Two of the most influential civil codes for Latin American jurisdictions have recently experienced important changes in their contract law provisions. On 1 August 2015, a new Civil and Commercial Code entered into force in Argentina

* This research has been financed by Universidad Panamericana through the grant 'Fomento a la Investigación UP 2018', code number 'UP-CI-2018-DER-GDL-02'.

** Professor of Law, Universidad Panamericana. School of Law. Calzada Álvaro del Portillo 49, Zapopan, Jalisco, 45010, Mexico. Ph.D. (Basel), LL.M. (UC Berkeley), LL.M. (Liverpool), LL.B. (UIA Mexico), DEUF (Lyon), emunoz@up.edu.mx. Ines Morfin Kroepfly, J.D., Universidad Panamericana, Guadalajara. 
(the '2015 CCCom'). ${ }^{1}$ This code replaced both the Civil Code of 1869 and the Code of Commerce of 1862, drafted by Velez Sarsfield. ${ }^{2}$ Argentina's old Civil Code, which did not particularly follow the French Civil Code, ${ }^{3}$ influenced other Latin American Civil Codes; it was fully adopted by Paraguay in $1866,{ }^{4}$ Uruguay in $1869,{ }^{5}$ Panama in 1916 and Nicaragua in $1904 .^{6}$

On 1 October 2016, new provisions on the law of obligations and contracts replaced the 1804 French Civil Code provisions on the same matter (the '2016 CC'). ${ }^{7}$ The French Civil Code had previously served as a model for different civil codes in Latin America. For example, the Chilean Civil Code of 1855 was drafted by Andres Bello on the basis of Las Siete Partidas, ${ }^{8}$ and, for those issues not covered by them, it also followed the 1804 French Civil Code. ${ }^{9}$ The Chilean Civil Code influenced the Civil Code of Colombia of $1858,{ }^{10}$ Ecuador of 1858, El Salvador of 1860, Honduras of 1880 (first Civil Code), Nicaragua of 1867 (first Civil Code) and Venezuela of 1862 (first Civil Code). ${ }^{11}$ In Mexico, the 1928 Federal Civil Code was based on the 1889 Spanish Civil Code, ${ }^{12}$ which in turn was modelled after the French Civil Code. ${ }^{13}$

The Argentinian 2015 CCCom and the French 2016 CC incorporate principles that have emerged from the case law of their respective courts. However, they also integrate a number of new rules that appear to have their most direct origin in international law instruments, such as the United Nations Convention on

1 See Law no 26,994 of 7 October 2014 and published on 8 October 2014, also Law no 27,077, published on 19 December 2014.

2 The Code of Commerce also had the participation of Eduardo Acevedo.

3 Velez Sarsfield admitted the influence of the Brazilian jurist Teixeira de Freitas on the method of the Argentine Civil Code. He also denied he had followed the French Civil Code method. Velez Sarsfield produced an eclectic code that has at its source many European doctrines. However, he explained that the majority of the articles were based on the principles contained in Las Siete Partidas, Nueva Recopilacion, and in Fuero Real, which were the Spanish statutes in force during the colony. See Luis Moisset De Espanés, 'El Método Del Código Civil', Cuadernos de Historia, 13 (2003) at 48; Sarsfield expressed: ..."I have followed such a discussed method of the Brazilian great jurist (Teixeira de Freitas) in his wise and broad Introduction to the Recompilation of the Laws of Brazil", see Alejandro Guzman Brito, Historia De La Codificación Civil En Iberoamerica (Navarra: Thomson Aranzadi, 2006) at 271 and 75.

4 Brito, Historia De La Codificación Civil En Iberoamerica at 333.

$5 \quad$ Ibid., at 284.

6 María Luisa Murillo, 'The Evolution of Codification in the Civil Law Legal Systems: Towards Decodification and Recodification', Journal of Transnational Law \& Policy, 11/1 (2001) at 9.

7 See Order no 2016-131 of 10 February 2016.

8 Las Siete Partidas was a Castilian statutory code first compiled during the reign of Alfonso X of Castile (1252-1284), with the intent of establishing a uniform body of normative rules for the kingdom. They had great significance in Latin America as well, where it was followed for centuries, up to the 19th century. See Edgardo Muñoz, Modern Law of Contracts and Sales in LatinAmerica, Spain and Portugal, ed. Ingeborg Schwenzer (International Commerce and Arbitration, 6; The Hague: Eleven International Publishing, 2011) at 7.

9 Brito, Historia De La Codificación Civil En Iberoamerica at 255.

10 Future Colombia, but also included other territories of current Ecuador, Panama and Venezuela.

11 Brito, Historia De La Codificación Civil En Iberoamerica at 243.

12 Kenneth W. Dam, 'Legal Institutions, Legal Origins, and Governance', Coase-Sandor Working Paper Series in Law and Economics, (2006) at 19.

13 Brito, Historia De La Codificación Civil En Iberoamerica at 295. 
Contracts for the International Sale of Goods of 1980 (CISG) and the UNIDROIT Principles on International Commercial Contracts (PICC).

The objective of this article is twofold. On the one hand, it identifies the main changes brought to the law of contracts and sales in Argentina and France. On the other hand, it compares those changes and discerns which of the new rules accomplish a better function and, thus, would be worthy of consideration as a model for future reform in other Latin American legal systems and beyond.

Section B introduces the comparative law method applied in our analysis, while Section $C$ addresses changes regarding the ambit of sales and mixed contracts. To continue, Section D deals with amendments to the rules on contract formation. Section E reviews the new provisions on validity of contracts, while Section $\mathrm{F}$ does it for pre-contractual duties and liability. Section $\mathrm{G}$ focuses on contract interpretation and supplementation rules, including the role of usages and practices in such tasks. Section $\mathrm{H}$ examines the obligations of the seller, while Section I compares the obligations of the buyer. Section J deals with provisions on risks transfer. Section $\mathrm{K}$ covers a wide range of new rules regarding remedies for breach of contract, including the right to withhold performance, specific performance, damages, avoidance and exemption due to force majeure and hardship.

\section{B Comparative Law Methodology Applied}

The functional method in comparative law is applied to our analysis of the new sales and contract law of Argentina and France. ${ }^{14}$ This methodology has many functions. One of them is to perform tertium comparationis: legal and non-legal rules, even doctrinally different ones, are comparable if they are functionally equivalent because they endeavour to accomplish or have the same function in their respective societies. ${ }^{15}$ The function of a rule is not defined by the intended purpose assigned by the legislature or the dogmatic reflections attached to it, but by the actual problem it endeavours to address or effectively tackles. ${ }^{16}$ The more specific the problem is in one community, the less likely it is that there are rules

14 Ralf Michaels, 'The Functional Method of Comparative Law', in Mathias Reimann and Reinhard Zimmermann (eds.), The Oxford Handbook of Comparative Law (London: Oxford, 2006) at 342. Also, owing to the advantages of this method, it is often used by the Commission on European Contract Law in its debates, see Ole Lando, 'The Common Core of European Private Law and the Principles of European Contract Law', Hastings International and Comparative Law Review, 21/4 (1998) at 814.

15 Efstathios K. Banakas, 'Some Thoughts on the Method of Comparative Law: The Concept of Law Revisited', RSP: Archiv Für Rechts- Und Sozialphilosophie / Archives for Philosophy of Law and Social Philosophy, 67/3 (1981) at 289; Michaels, 'The Functional Method of Comparative Law', at 342; but see Julie De-Coninck, 'The Functional Method of Comparative Law: “Quo Vadis"?', Rabels Zeitschrift Für Ausländische Und Internationales Privatrecht / the Rabel Journal of Comparative and International Private Law (74: Mohr Siebeck GmbH \& Co. KG, 2010) at 323, suggesting that empirically substantiated behavioural patterns should be the standard of comparison, so that legal comparatists can go beyond the reliance on mere constructed problems as a starting point for their inquiries.

16 Michaels, 'The Functional Method of Comparative Law', at 367. 
whose function is the same in a different community. ${ }^{17}$ But comparatists who do not find universality of a problem because of its high degree of specificity, can always step down one level to compare those general needs shared by most societies from which the specific problem derives. ${ }^{18}$

Contracts in general, and sales in particular, give rise to problems that most world societies share. All communities have a need to solve the problems related to the enforcement of promises, their interpretation or the remedies required to redress their infringement. These are a sort of universal problem. But from these problems other specific needs derive, and thus rules may be in place to address them. The law on damages may be there to provide compensation for breaches of contracts, but some societies may have an additional need to specify particular methods of compensation, i.e. market-based damages, disgorgement of profits, etc.

In addition, functional equivalents may not be known until they appear in the compared legal system. ${ }^{19}$ Late appearance of functional equivalents may reflect a lack of problem or necessity to be solved in the past or a voluntary or negligent omission by the legal actors of the legal system concerned. But the appearance of new rules allows the comparatist to identify the underlying problem and to recognize their function. Still, how do we know that the function of damages indemnity is deterrence of wrongdoings or punishment and not compensation or effectuation of certain societal values, or all of the above? ${ }^{20}$ When everything is taken into consideration, (the)

similarity of results to certain fact[ual] situation[s], regardless of the difference in doctrine, strongly suggest that the respective legal institutions can be different (but functionally equivalent) responses to a similar problem. ${ }^{21}$

Against this background, the functional method will help us to identify old and new rules pursuant to the functions they should perform in Argentina and France. The functions of the rules we are about to examine are broadly expressed in the titles and subtitles of this work. For example, the function and subfunctions of enforcing agreements concerned the rules on contract formation analysed in Section D; the function of preventing the effects of contract in cases of mistake, duress, gross disparity is expressed in the rules on validity in Section $\mathrm{E}$; the rules that function in redressing the consequences of a breach of negotiations are examined in Section $\mathrm{F}$, while those concerning the effects of a breach of contract are examined in Section K concerning remedies; and so on.

Accordingly, this article examines the solutions developed by Argentina and France in order to give an answer to issues arising in contracts and sales in

17 Banakas, 'Some Thoughts on the Method of Comparative Law: The Concept of Law Revisited', at 291.

18 Michaels, 'The Functional Method of Comparative Law', at 368.

19 Ibid., at 369.

20 Ibid., at 368 .

21 Ibid., at 369. 
particular. The English legal terms used to express such issues are taken from the CISG English version, and for those issues that are not governed by the CISG, they are taken from the PICC English version. The legal terms in Spanish or French were not literally translated into English, but rather the event that they express, or the function that they serve, has been converted into the uniform law (CISG or PICC) English terms that express the same function or event.

The functional method of comparative law may also serve as an evaluative criterion or yardstick to determine what makes 'better law'. ${ }^{22}$ In order to apply this method, the comparative lawyer is forced to work under the assumption or simple working hypothesis that one rule accomplishes its function better than another. ${ }^{23}$ For example, in two rules that are comparable because they endeavour to perform the same function, the better law may be the one that, after evaluation, has a better doctrinal formulation and/or has shown better empirical results. ${ }^{24}$ In this regard, a relative difference may determine superiority. But it is worth noting that any evaluation of functional equivalent rules is valid only with regard to the function scrutinized. One legal system is not better than another in absolute terms; at best it may be better regarding a certain function. ${ }^{25}$ With that in mind, the functional method will help us to determine which legal rule is better: Argentina's new law or France's new law.

\section{The Ambit of Sales}

France maintains a dual system that distinguishes between civil contracts (C2C) governed by the 2016 CC and business contracts (B2B) governed by the code of commerce. Argentina has abandoned this old dichotomy with the 2015 CCCom; now a unique body of rules governs both types of transactions. As limited as it is today in France, ${ }^{26}$ the French dualism between $\mathrm{C} 2 \mathrm{C}$ and B2B contracts does not reflect a modern or international conception of the law of contracts. The CISG, the PICC and the Principles of European Contract Law (PECL) do not draw such a distinction. Argentinean law offers a better solution in that respect. The deferential treatment of $\mathrm{C} 2 \mathrm{C}$ transactions, still present in many Latin American

22 Ibid., at 342; because under the functionalism method "the better of several laws is that which fulfils its function better than the others".

23 Ibid., at 374; Ralf Michaels, 'Explanation and Interpretation in Functionalist Comparative Law A Response to Julie De Coninck', Rabels Zeitschrift Für Ausländisches Und Internationales Privatrecht / The Rabel Journal of Comparative and International Private Law, 74/2 (2010) at 358, 59.

24 Michaels, 'The Functional Method of Comparative Law', at 374; Michaels, 'Explanation and Interpretation in Functionalist Comparative Law - A Response to Julie De Coninck', at 358, 59.

25 Michaels, 'The Functional Method of Comparative Law', at 375.

26 "Yet, in practice, it has lost much of its importance. Under our French legal systems the rules contained in the Code civil apply to commercial contracts, unless the Code de Commerce or commercial usages lead to other solutions. There are very few specific rules for commercial contracts, especially now that the law of prescription has been reformed. In our law faculties, Contrats civils et commerciaux are taught in the same course on the law of contracts or obligations", see Bénédicte Fauvarque-Cosson, 'The French Contract Law Reform in a European Context', ELTE Law Journal, 1 (2014) at 71. 
countries, ${ }^{27}$ has lost relevance with the emergence of consumer protection laws for business to consumer (B2C) transactions. Contract law must promote voluntary exchanges to foster economic growth in society, which can be accomplished by deferring to individual autonomy, reducing transactions costs and providing stability in transactions. ${ }^{28}$ From a law and economics perspective, a single set of rules for consumer to consumer (C2C) and business to business (B2B) avoids the lengthy and costly pretrial issues regarding the interplay between civil and commercial codes in contracts. As one scholar has put it, "[a]fter all, economic analysis is in essence a refined functional method, one that measures legal rules not by their doctrinal consistency but by their ability to fulfil societal needs". ${ }^{29}$

Both laws continue to define the contract of sales as the covenant whereby a party agrees to deliver a thing and the other to pay a price in exchange. ${ }^{30}$ The Argentine 2015 CCCom includes the obligation to transfer the property in the same provision, ${ }^{31}$ a choice that keeps the Roman law traditio requirement for the passing of property. The French law prefers its 1804 rule, in which title passes to the buyer as of the parties' meeting of minds, irrespective of whether the thing was delivered or the price paid..$^{32}$

Argentina lost an opportunity to depart from its narrow definition of 'thing' as a tangible object. ${ }^{33}$ France, on the other hand, suppressed any reference to tangible objects: "capable of being determined" is the only criterion. ${ }^{34}$ The definition of thing in Argentina, as a tangible object, will cause debate regarding the possibility to sell modern merchandise like software. ${ }^{35}$ By suppressing the reference to tangible objects, the French contract law prevented the dispute among scholars as to whether intangible objects can be classified as 'things',

27 Except for Brazil, Peru, Paraguay and now Argentina; see Muñoz, Modern Law of Contracts and Sales in Latin-America, Spain and Portugal at 41.

28 See Larry A. Dimatteo and Daniel T. Ostas, 'Comparative Efficiency in International Sales Law', American University International Law Review, 26/2 (2011) at 386. By avoiding pretrial issues, two of these main functions are promoted. On the one hand, transaction costs are lowered since the direct procedural costs are reduced. There are two types of costs that the legal procedure aims to minimize: i) the direct costs, which are the costs involved in a litigation process, and the ii) error costs, which are the social costs resulting from the judicial system's mistakes in the resolution of cases; see George M. Cohen, 'Posnerian Jurisprudence and Economic Analysis of Law: The View from the Bench', University of Pennsylvania Law Review, 133/5 (1985) at 1127. On the other hand, by providing one set of applicable rules, the framework is clearer for the parties, which enhances the stability and predictability of the law.

29 Ralf Michaels, 'The Second Wave of Comparative Law and Economics?', The University of Toronto Law Journal, 59/2 (2009), 197-213 at 198.

30 Argentina Art. 1123 of the 2015 CCCom; France Art. 1582 of the 2016 CC.

31 Argentina Art. 1123 of the 2015 CCCom: "Hay compraventa si una de las partes se obliga a transferir la propiedad de una cosa y la otra a pagar un precio en dinero".

32 France Art. 1583 of the 2016 CC.

33 Art. 2311 of the old Argentinian code was deleted; however, Art. 16 of the 2015 CCCom still defines thing as 'objetos materiales' or tangible objects.

34 The old Art. 1129 CC was deleted and new Art. 1163 of the French 2016 CC now applies.

35 Although it is debatable whether software qualifies as a corporal/tangible object or not. See Edgardo Muñoz, 'Software Technology in Cisg Contracts', Uniform Law Review, 24/2 (2019) at 287. 
which provides stability in the transactions in which these kinds of new goods are involved. To illustrate, this debate has already prevented a uniform approach among CISG scholars, since there are divergent opinions as to whether 'software' and other intangibles may qualify as 'goods'. ${ }^{36}$ Accordingly, the French definition may be better law.

The Argentine 2015 CCCom took the opportunity to address mixed contracts. Modelled by Article 3 CISG, ${ }^{37}$ Article 1125 now states that a contract involving labour or services may still be governed by the provisions on sales, unless the service or labour obligations are the main ones in the transaction. The sales provisions will also apply, unless the buyer supplies a substantial part of the materials required for manufacturing or producing the goods. France chose not to codify the case law rules it had developed for complex agreements and that followed a different approach; even if several agreements serve one and the same economic purpose, each and every legal regime applies. ${ }^{38}$ The CISG - now Argentinean approach - may accomplish its function better by clarifying from the outset the applicable rules on the basis of identifiable criteria of 'main obligations' or 'substantial part of materials'.

\section{Contract Formation}

Argentina continues to require a licit 'cause' as an element of the existence and validity of contracts. ${ }^{39}$ The choice is unfortunate owing to useless debates generated around this concept and the difficulties in establishing its relevance in the formation of contracts. ${ }^{40}$ Some Argentinean scholars still submit that the new Article 1013 comprises the motivational cause pursued by the parties. ${ }^{41}$ As pointed out in a different contribution, this type of cause is so changeable, alterable and particular to the parties' inner expectations that it would be unfair to rely on the accomplishment of internal ambitions to recognize the existence or validity of a contract. ${ }^{42}$ France has been more receptive to the modern doctrine proposals and avoided the unnecessary problems brought by the old concept of

36 See Hiroo Sono, 'The Applicability and Non-Applicability of the Cisg to Software Transactions', in Camilla B. Andersen and Ulrich G. Schroeter (eds.), Haring International Commercial Law across National Boundaries: Festschrift for Albert H. Kritzer on the Occasion of His Eightieth Birthday (London: Wildy, Simmonds \& Hill Publishing, 2008), 14 at 515.

37 M. Alejandro Garro and Alberto L Zuppi, 'El Nuevo Código Civil Y Comercial Y La Convención De Viena Sobre Compraventa Internacional', (2015) at 4.

38 See Ingeborg Schwenzer, Pascal Hachem, and Christopher Kee, Global Sales and Contract Law (London: OUP, 2011) at 119, para. 843, fn. 87.

39 Argentina Art. 1013 of the 2015 CCCom.

40 See Muñoz, Modern Law of Contracts and Sales in Latin-America, Spain and Portugal at 79-86.

41 Gustavo Caramelo, 'Art. 1013', in Marisa Herrera and Gustavo \& Sebastián Picasso Caramelo (eds.), Código Civil Y Comercial De La Nación Comentado (III; Buenos Aires: Ministerio de Justicia y Derechos Humanos, 2015a) at 410, 11.

42 Muñoz, Modern Law of Contracts and Sales in Latin-America, Spain and Portugal at 81. 
'cause'; 43 the French 2016 CC no longer includes the 'cause' as a validity element for contract formation. ${ }^{44}$ Today, two clearer validity provisions on false and illicit agreements were added. ${ }^{45}$ French law became the better law. This is because, first, the futile debates around this concept will be limited; second, the incorporation of two new clearer rules will foster stability in the contract formation process; and, third, "the cause attempts to explain why a party contracted", which only increases subjectivity and complexity in determining the intent of a party. ${ }^{46}$ The latter is unnecessary since, irrespective of the reasons why the parties decided to contract, a promise should be enforceable "if the promisor and promisee both wanted enforceability when it was made". ${ }^{47}$ Unless there is manifest unconscionable conduct, each party is in a better position to know what will advance its own interests, and therefore, by contracting, both parties are better off and no one is worse off, which is a Pareto-efficient scenario. ${ }^{48}$

In France, the traditional theory of offer and acceptance was introduced in the 2016 CC in a whole new subsection with fifteen articles. ${ }^{49}$ Argentina still relies on the same traditional theory of contract formation. ${ }^{50}$ However, Argentina now stipulates that any conduct of the parties may also suffice to demonstrate the existence of agreement. ${ }^{51}$ The addition was rightly taken from Article 2.1 PICC. ${ }^{52}$ The traditional approach in France is not always sufficient to address new trade realities where contracts are concluded after prolonged (and often discontinuous) negotiations without identifiable sequences of offers and acceptances. Under the Argentine new rule, a contract may be concluded even if the exact moment of consent to $\mathrm{X}$ or $\mathrm{Y}$ obligation cannot be determined, provided conduct is enough to demonstrate agreement.

In both legal systems, the offer must indicate intention to be bound, as well as the essential elements of the contract: in the case of sales, the goods and the price or a way to determine both. ${ }^{53}$ The price may be subsequently determined by

43 Alain Bénabent, Droit Des Obligations (16th edn., Précis Domat Droit Privé; France: LGDJ, 2017) at 165, para. 200; Francois Chénedé, Le Nouveau Droit Des Obligations Et Des Contrats: Consolidations - Innovations - Perspective (France: Dalloz, 2016) at 85, para. 23.271.

44 France Art. 1128 of the 2016 CC, compared with Art. 1108 of the old CC.

45 France Arts. 1162 and 1169 of the 2016 CC. See also Chénedé, Le Nouveau Droit Des Obligations Et Des Contrats: Consolidations - Innovations - Perspective at 85, para. 23.271.

46 Alexis Downe, 'The Reform of the French Contract Law: A Critical Overview', Revista da Faculdade de Direito, 61/1 (2016) at 50.

47 See Robert Cooter and Thomas Ulen, Law \& Economics (5th edn.; Boston: Pearson, 2008) at 202.

48 See Dimatteo and Ostas, 'Comparative Efficiency in International Sales Law', at 387.

49 Former Art. 1108 only referred to "consent of a party who obligates itself", see Solène Rowan, 'The New French Law of Contract', International and Comparative Law Quarterly, 66/4 (2017) at 8; Mustapha Mekki, 'France - The French Reform of Contract Law: The Art of Redoing without Undoing', Journal of Civil Law Studies, 10/1 (2018) at 235.

50 Argentina Art. 971 of the 2015 CCCom.

51 Ibid.

52 Alejandro A. Freytes, 'Caracterización Del Consentimiento Contractual En El Nuevo Código Civil Y Comercial De La Nación', Revista de Derecho Notarial y Registral de la Universdiad de Blas Pascal, 3 (2016) at 245

53 France Arts. 1114, 1163 of the 2016 CC; Argentina Art. 972 of the 2015 CCCom. 
a third party. ${ }^{54}$ The Argentine law goes a step further; following Article 55 CISG closely, ${ }^{55}$ Article 1143 of the 2015 CCCom stipulates that where the contract does not expressly or implicitly fix or make provision for determining the price, it is considered, in the absence of any indication to the contrary, that the parties have impliedly made reference to the price generally charged at the time of the conclusion of the contract for such goods sold under comparable circumstances in the trade concerned. With this provision, Argentina rightly departed from its old rule (former Article 1354 CC), which used to favour the price at the time and place of delivery. The new rule avoids speculations by the seller, which, in some instances, may be entitled to choose a date of delivery. France did not take the opportunity to enact a similar provision. The authors thus prefer the Argentinean approach. However, in the case of framework agreements, the French 2016 CC recognizes the agreement allowing a party to fix the price unilaterally, provided that its amount is motivated. ${ }^{56}$

Following the CISG-PICC solution, ${ }^{57}$ offers may be withdrawn if the withdrawal reaches the offeree before or at the same time as the offer. ${ }^{58}$ Both systems also stipulate that an offer that fixes a time for acceptance may not be revoked during that time. Departing from the CISG and PICC, ${ }^{59}$ Argentine and French laws now stipulate that, in the absence of a period of time for acceptance, offers are irrevocable during a reasonable period of time after reaching the offeree. ${ }^{60}$ Regrettably, this addition only increases uncertainty during the formation process; the offeror remains bound by its offer for an uncertain time, the reasonability test is left to the adjudicator, which is inefficient and costly for both parties. Contract law can help to lower these costs as much as possible by providing strict rules and a clear framework, instead of flexible standards. ${ }^{61}$

The French Civil Code now clarifies that unlawful revocation stops the contract formation and gives rise to extra-contractual liability against the offeror, without obliging the latter to compensate the expectation interest of the offeree. ${ }^{62}$ The rule has logic when the irrevocable offer is revoked before acceptance, but the French law could have clarified that, in case of revocation

54 France Art. 1592 of the 2016 CC; Argentina Art. 1133 of the 2015 CCCom.

55 Garro and Zuppi, 'El Nuevo Código Civil Y Comercial Y La Convención De Viena Sobre Compraventa Internacional', at 5.

56 Art. 1164 the 2016 CC; in case of an abusive price fixed by one party, the disadvantaged party may request damages or avoidance of the contract; see Eduardo C. Méndez-Sierra and Marcelo C. Quagilia, 'El Nuevo Derecho De Las Obligaciones T De Los Contratos En Francia', El Derecho, No. 14.172 (2017) at 4.

57 Art. 15(2) CISG and Art. 2.1.3 PICC.

58 Argentina Art. 975 of the 2015 CCCom; France Art. 1115 of the 2016 CC.

59 Art. 16 CISG and Art. 2.1.4 PICC.

60 Argentina Art. 974 of the 2015 CCCom; France Art. 1116 of the 2016 CC.

61 See Cooter and Ulen, Law \& Economics at 220. See Giesela Ruhl, 'The Battle of the Forms: Comparative and Economic Observations', University of Pennsylvania Journal of International Law, $24 / 1$ (2003) at 212.

62 France Art. 1116 of the 2016 CC. 
after acceptance, the contract would be deemed concluded and, thus, any refusal by the offeror to perform may give rise to contractual expectation damages. ${ }^{63}$

In relation to the time of contract conclusion, Argentina abandoned the dispatch rule, ${ }^{64}$ in favour of the reception rule, which is now expressly followed in France. ${ }^{65}$ As under Articles 18 CISG and 2.1.6(2) PICC, the contract is concluded when the acceptance reaches the offeror. The rule makes sense in two legal systems that restrict revocation of offers during a reasonable period of time after the offer reached the offeree; it allows the offeror to avoid expectation damages liability with a revocation dispatched before the acceptance reaches him.

The 'mirror-image' rule of contract formation already existing in Argentina, is now enacted in the French Civil Code; an acceptance that alters the offer is lacking effect and constitutes only a counter-offer. ${ }^{66}$ That being said, both legal systems seem to also incorporate the knockout rule of contract conclusion found in Article 2.1.22 PICC. On the one hand, Article 982 of the 2015 Argentine CCCom states that when an offer and an acceptance concur on essential elements, a partial agreement will be deemed concluded on those terms. On the other hand, Article 1119 of the 2016 French CC states that in case of discrepancies between the standard terms respectively relied on by the parties, opposing clauses lack effect. The incorporation of the knockout rule increases certainty in a battle of forms scenario. In addition, the knockout rule entails lower transaction costs than the straightforward application of the mirror-image rule, since it does not incentivize the parties to continue sending documents to each other to ensure that their standard terms arrive last; the content of the contract is not determined chronologically but takes into consideration other criteria, i.e. the common intention of the parties. ${ }^{67}$ Incidentally, this rule promotes individual autonomy and free contracting, firstly, by allowing a contract to be concluded and enforceable if the essential elements of the transaction have been agreed upon by the parties, even if the secondary terms are contradictory and, secondly, by incorporating into the contract the terms about which there is real agreement. ${ }^{68}$ Therefore, this rule is a welcome model for reform in other jurisdictions.

Both systems now incorporate rules on standard terms and adhesion contracts. ${ }^{69}$ Following Article 2.1.19 PICC, standard terms are defined as non-

63 See Muñoz, Modern Law of Contracts and Sales in Latin-America, Spain and Portugal at 99.

64 Argentina former Arts. 1154 CC and 213, 215 of the CCCom.

65 Argentina Art. 980 of the 2015 CCCom; France Art. 1121 of the 2016 CC.

66 Argentina Art. 978 of the 2015 CCCom (former Art. 1154 CC); France Art. 1118(3) of the 2016 CC.

67 See Schwenzer, Hachem, and Kee, Global Sales and Contract Law at 171, para. 12.28; Victor Goldberg, 'The Battle of the Forms: Fairness, Efficiency, and the Best-Shot Rule', Oregon Law Review, 76 (1997), cited in Omri Ben-Shahar, 'An Ex-Ante View of the Battle of the Forms: Inducing Parties to Draft Reasonable Terms', International Review of Law and Economics, 25/3 (2005) at 353; Ruhl, 'The Battle of the Forms: Comparative and Economic Observations', at 212.

68 See Peter Schlechtriem and Petra Butler, Un Law on International Sales (Berlin: Springer, 2009) at 82, para. 92.

69 About the economic implications adhesion contracts, see Cooter and Ulen, Law \& Economics at 302. 
negotiable clauses drafted in advance by one of the parties. ${ }^{70}$ Regarding their incorporation, they shall be provided prior to or at the time of the contract conclusion. ${ }^{71}$ The Argentine CCCom requires them to be understandable and be drafted in a clear, easy and complete fashion. ${ }^{72}$ The requirement is more specific than in Article 2.1.20 PICC regarding surprising standard terms. Accordingly, certainty could be fostered by the Argentine solution.

\section{E Validity of Contracts}

Both codes provide for the traditional mechanisms to redress or rescind the contract where the free and informed will of a party or parties is found to have been affected by relevant conduct or circumstances. Few fundamental changes have been made in this area. In lieu of the age of twenty one, legal capacity of natural persons in Argentina is now acquired at the age of eighteen, ${ }^{73}$ as had been the case in France. ${ }^{74}$ The age of eighteen provides uniformity with other jurisdictions in the region.

Lack of capacity may be invoked by the incapable party, ${ }^{75}$ but Argentina also allows a party to rely on the other party's lack of capacity in good faith and when such party has suffered important damages. ${ }^{76}$ With regard to corporations, the French Code now states that their capacity is limited by the rules applicable to them, ${ }^{77}$ i.e. their object. ${ }^{78}$ The same rules may be inferred from Article 150 of the Argentine CCCom.

The 'essential mistake' leads to voidability of the contract. France has maintained a subjective definition of 'essential mistake, ${ }^{79}$ while Argentina favours a casuistic and objective approach. ${ }^{80}$ The main difficulty in applying the subjective criterion in the French Civil Code is that, in case of dispute, parties have difficulty in agreeing on what the essential qualities of their transaction were, increasing future legal costs. In order to avoid the evidentiary problem of the subjective criterion, Article 3.2.2 PICC applies the objective criterion of the

70 Argentina Art. 984 of the 2015 CCCom; France Art. 1110(2) of the 2016 CC.

71 Argentina Art. 985 of the 2015 CCCom; France Art. 1119 of the 2016 CC.

72 Argentina Art. 985 of the 2015 CCCom.

73 Argentina Art. 25 of the 2015 CCCom (former Art. 126 CC). See Silvia E. Fernández, '25', in Ricardo Rocca et al. (eds.), Código Civil Y Comercial De La Nación Comentado (I: Ministerio de Justicia y Derechos Humanos, 2015) at 61.

74 France Art. 338 of the 2016 CC.

75 France Art. 1118 of the 2016 CC.

76 Argentina Art. 338 of the 2015 CCCom.

77 France Art. 1145 of the 2016 CC.

78 Bénabent, Droit Des Obligations at 58, para. 50.

79 France Arts. 1132 and 1133 of the 2016 CC.

80 Argentina Art. 267 of the 2015 CCCom: including mistake over: a) the nature of the act; b) the object involved in the transaction; c) the substantial quality of the asset that has been determinant consenting according to the common assessment or the circumstances of the case; d) the relevant personal reasons that have been expressly or tacitly informed; e) the person with whom the act was held or to which the act refers if it was decisive for its conclusion. 
reasonable person. ${ }^{81}$ Hence, the authors consider that the objective criterion offers a more economically efficient rule. ${ }^{82}$

Reflecting case law developments, contractual fraud now includes not only positive acts, but also omissions, inactivity or silence by a party, inducing the misleading party to conclude the contract. ${ }^{83}$ Following Article 3.2.8 PICC, today, both codes expressly state that fraud may be performed by third parties, including employees, agents, etc. for the benefit of any contracting party. ${ }^{84}$ The addition is welcome because it makes the vicarious liability, which also applies in tort matters, clearer.

The consequence for mistake, contractual fraud or duress is still the voidability of the contract determined by the adjudicator. ${ }^{85}$ France added that the voidability and its effects may also be agreed on by the parties; ${ }^{86}$ such solution should be implied in the Argentinean system. Also, the disadvantaged party may confirm the contract affected by any of the aforementioned grounds. ${ }^{87}$ Termination on the grounds of voidability has a retroactive effect; the parties must be placed back to the position they were in before the conclusion of the contract and thus the parties should return their respective performances. ${ }^{88}$ The parties shall also return the fruits of performances. Different to Argentina CCCom, France has abandoned the old distinction between the holder of fruits or benefits in good faith; in France the holder in good faith should also return anything obtained from the rescinded contract. ${ }^{89}$ Termination will entitle the disadvantaged party to claim damages for any losses in accordance with the rules on extra-contractual liability or tort, ${ }^{90}$ i.e. damages to compensate the disadvantaged party's reliance interest, which means to place it in the same position in which it would have been if it had not concluded the contract, as stated in Article 3.2.16 PICC. ${ }^{91}$

81 According to which a mistake leads to the voidability of the contract if the mistake was of such importance that a reasonable person in the same situation as the party in error would only have concluded the contract on materially different terms or would not have concluded it at all if the true state of affairs had been known.

82 By applying an objective approach, transaction costs decrease since these are normally reduced by applying strict rules and a clear framework, instead of flexible standards; see Ruhl, 'The Battle of the Forms: Comparative and Economic Observations', at 212. Also, the direct procedural costs decrease since the evidentiary problem of the subjective criterion is avoided by providing an objective and clear basis to prove an essential mistake.

83 Argentina Art. 271 of the 2015 CCCom; France Art. 1137 of the 2016 CC; Bénabent, Droit Des Obligations at 93, para. 102.

84 Argentina Art. 274 of the 2015 CCCom; France Art. 1138 of the 2016 CC.

85 Argentina Art. 390 of the 2015 CCCom; France Art. 1178 of the 2016 CC.

86 France Art. 1178 of the 2016 CC.

87 Argentina Art. 388 of the 2015 CCCom; France Art. 1182 of the 2016 CC.

88 Argentina Art. 390 of the 2015 CCCom; France Art. 1178 of the 2016 CC.

89 Argentina Art. 1935 of the 2015 CCCom; France Art. 1352-3 of the 2016 CC.

90 Argentina Arts. 275 and 278 of the 2015 CCCom; France Art. 1178(4) of the 2016 CC.

91 Art. 3.2.16 PICC: "Irrespective of whether or not the contract has been avoided, the party who knew or ought to have known of the ground for avoidance is liable for damages so as to put the other party in the same position in which it would have been if it had not concluded the contract". 
True to its old law, France maintains the principle of subjective reciprocity, excluding the termination of the contract on grounds of gross disparity. ${ }^{92}$ Argentina, on the other hand, allows claims for gross disparity in contract formation; ${ }^{93}$ a possibility that already existed for civil contracts and now extends to business transactions in light of the dual nature of the 2015 CCCom. ${ }^{94}$ Argentine gross disparity elements coincide with those stated in Article 3.2.7 PICC: the criterion is unjustifiable and delegates excessive advantage over to one party. The evidentiary elements are also similar: necessity, ignorance, inexperience, though the PICC go further to include lack of bargaining skill. Also the remedies concur: the disadvantaged party may claim termination of the contract or adaptation. It is arguable whether this type of provisions serve its function of protecting the society as a whole from unfair dealings. Argentine law and the PICC require blameworthy behaviour by one party, which can lead to subjective interpretations and evidentiary problems, which, in turn, may result in unwarranted legal proceedings in business settings.

In terms of formal requirements, Argentina has abolished the 'in writing' form as the only valid means of proof for some contracts. ${ }^{95}$ The law no longer subjects the sale of goods to any form requirement, and thus the parties may use any means to conclude their contract. ${ }^{96}$ This welcome development should lead Argentina to withdraw its declaration under Article 96 CISG and recognize, from now on, the validity of any CISG contract whose conclusion or modification has not been stated in writing. ${ }^{97}$ In order to make the law clearer, the French Civil Code now expressly states the freedom of form principle; contracts are consensual (free of formalities), except when the law requires a particular form or solemnity. ${ }^{98}$ In addition, both legal systems recognize the principle of functional

92 France Art. 1168 of the 2016 CC (former Art. 1188 CC) states that the lack of equivalence in the performances is not a ground for contract nullity, unless the law provides otherwise. The clear exception is transactions with minors and legally disabled, see Chénedé, Le Nouveau Droit Des Obligations Et Des Contrats: Consolidations - Innovations - Perspective at 84, para. 23.261.

93 Argentina Art. 332 of the 2015 CCCom.

94 Former Art. 954 of the French CC.

95 Those beyond ten thousand pesos; see former Art. 1193 CC, and Muñoz, Modern Law of Contracts and Sales in Latin-America, Spain and Portugal at 177.

96 Argentina Art. 284 of the 2015 CCCom. There are divergent approaches as to the efficiency of the 'in writing' requirement. For example, "some argue that requiring a writing promotes transactional certainty and consequently reduces dispute resolution costs. Allowing oral testimony to establish a contract creates a moral hazard, as parties are incentivized to fabricate obligations where none were intended. However, when the parties believe that a writing is not necessary, a legal regime's requirement of a writing increases transaction costs. Sometimes the negotiation and drafting costs of placing a contract in writing exceed the benefits from entering the contract and a mutually beneficial trade is forgone. In addition, by requiring a writing, an opportunistic party may seek to nullify a bona fide oral agreement and escape a contractual obligation"; see Dimatteo and Ostas, 'Comparative Efficiency in International Sales Law', at 400.

97 Muñoz, Modern Law of Contracts and Sales in Latin-America, Spain and Portugal at 178.

98 France Art. 1172 of the 2016 CC; Chénedé, Le Nouveau Droit Des Obligations Et Des Contrats: Consolidations - Innovations - Perspective at 119, para. 23.382. 
equivalence with regard to the use of electronic communication; the in writing form' and 'signed documents' can take place in any medium. ${ }^{99}$

\section{F Pre-contractual Duties and Liability}

Pre-contractual duties and liability were issues governed by case law in Argentina and France. ${ }^{100}$ Today, their civil codes contain specific rules that substantially follow Article 2.1.15(1) PICC. ${ }^{101}$ The principle under French law (implicit in Argentina) is that parties are free to start, continue or stop negotiations. ${ }^{102}$ However, parties must abide by the obligation to negotiate in good faith under both systems. ${ }^{103}$ None of the codes define good faith in this context. Article 2.1.15 PICC considers bad faith to enter or continue negotiations without intention to reach an agreement. The Argentine CCCom requires "not to unjustifiably frustrate" negotiations when "the other party relied, with no fault, in the conclusion of the contract". ${ }^{104}$ These extra elements make Argentine rules even better law as they will help in determining the contours of pre-contractual duties.

In France, negotiating parties are expressly subject to a duty to furnish relevant information for the contract conclusion, excluding data regarding the value of performance. ${ }^{105}$ A similar obligation may be implicit in Argentina's Article 1100 of the 2015 CCCom applicable to B2C transactions ${ }^{106}$ or the general obligation to act in good faith. ${ }^{107}$ Both countries also impose a duty to refrain from disclosing any confidential information supplied by the parties during the negotiations. ${ }^{108}$ The Argentine provisions seem to be more closely influenced by Article 2.1.16 PICC, since the remedy for breach of that duty may include compensation based on the benefit received by the other party. ${ }^{109}$ The rule is interesting from the point of view of the debate around the full compensation

99 Argentina Arts. 286 and 288 of the 2015 CCCom; France Arts. 1174, 1366, 1377 of the 2016 CC.

100 Chénedé, Le Nouveau Droit Des Obligations Et Des Contrats: Consolidations - Innovations Perspective at 29; Rowan, 'The New French Law of Contract', at 9.

101 France Arts. 1112, 1112-1 and 1112-2 of the 2016 CC; Argentina Arts. 990, 991 and 992 of the 2015 CCCom.

102 France Art. 1112 of the 2016 CC.

103 Argentina Art. 991 of the 2015 CCCom; France Art. 1112 of the 2016 CC.

104 Argentina Art. 991 of the 2015 CCCom.

105 France Art. 1112-1 of the 2016 CC.

106 Argentina Art. 1100 of the 2015 CCCom: the supplier is obliged to provide clear and detailed information to the consumer regarding the essential characteristics of the goods and services it provides, the conditions of its commercialization and any other circumstance relevant to the contract.

107 The general duty to act in good faith is established in Art. 1198 of the Argentina 2015 CCCom. The duty to act in good faith during the negotiations is stated in Art. 991 of the same body of law.

108 Argentina Art. 992 of the 2015 CCCom; France Art. 1112-2 of the 2016 CC. Commenting that the rule reinforces the general obligation to act in good faith, see Sophie Pellet, 'Négotiations Et Avant-Contrat', in Mathias Latina (ed.), La Réforme Du Droit Des Contrats En Pratique (Paris: Dalloz, 2017) at 27.

109 Argentina Art. 992 of the 2015 CCCom. 
principle vs. the possibility to compensate a party with the benefits obtained by the breaching party, i.e. disgorgement of profits. ${ }^{110}$

The scope of liability (compensation) is important in this context. France expressly bars compensation of lost opportunity and lost profits. According to French scholars, the compensation afforded is thus limited to costs incurred in connection with the negotiations; ${ }^{111}$ for example, the cost of the trips, meetings, legal advice, telephone calls and documentation produced with views of reaching an agreement. ${ }^{112}$ Argentina's new code does not state limits to the obligation to compensate any damage arising out this type of pre-contractual breach. ${ }^{113}$ One author considers that the current wording of Article 991 of the 2015 CCCom may allow compensation beyond reliance interests. ${ }^{114}$ However, the pre-contractual liability system adopted by Argentina (possibly influenced by PICC) most likely limits compensation to the expenses incurred in the negotiations and lost opportunity to conclude another contract with a third person (so-called reliance or negative interest); a party may not recover the profit that would have resulted if the original contract had been concluded (so-called expectation or positive interest). ${ }^{115}$ The possibility to recover damages for lost opportunities may make Argentina's law better in dissuading the breach of pre-contractual duties. That being said, determining the prevented chance or lost opportunity is a difficult task; it requires concrete evidence of parallel business chances and the real loss incurred; it must be confined only to the loss of other opportunities to contract with a third party. ${ }^{116}$

\section{G Interpretation and Supplementation}

In Argentina and France, contracts shall be interpreted in accordance with the parties' shared intention. ${ }^{117}$ This rule embodies a subjective criterion requiring adjudicators to discover the real intention of the parties, beyond the literal meaning of their statements. This approach works together with other rules of systematic interpretation designed to help in the interpretative task. These rules call for interpreting the contract's clauses conjunctively, giving to the unclear

110 See generally Edgardo Muñoz and David Obey Ament-Guemez, 'Calculation of Damages on the Basis of the Breaching Party's Profits under the Cisg', Journal of International Commercial Law, $8 / 2$ (2017) at 201, where it is submitted that under some limited circumstances damages' calculations may take into account the benefits that the breaching party obtained from the breach of a CISG contract because, in some scenarios, the approach offers the most reasonable way to achieve full compensation and enhances proof efficiency.

111 Virginie Colaiuta, 'Recent Reform of the French Civil Code', Construction Law International, 12/1 (March 2017) at 36.

112 Muñoz, Modern Law of Contracts and Sales in Latin-America, Spain and Portugal at 234.

113 Argentina Art. 991 of the 2015 CCCom.

114 Gustavo Caramelo, 'Art. 991', in Marisa Herrera and Gustavo \& Sebastián Picasso Caramelo (eds.), Código Civil Y Comercial De La Nación Comentado (III; Buenos Aires: Ministerio de Justicia y Derechos Humanos, 2015b) at 390.

115 See PICC Art. 2.1.15, Comment 2.

116 Muñoz, Modern Law of Contracts and Sales in Latin-America, Spain and Portugal at 234.

117 Argentina Art. 1061 of the 2015 CCCom; France Art. 1188 of the 2016 CC. 
clauses the significance resulting from the contract taken as a whole or giving to them the meaning that better suits the overall contract. ${ }^{118}$

The problem with this subjective criterion is an evidentiary one. In case of dispute, the parties often claim opposite meanings for key clauses or statements and little or no evidence exists of a common understanding. On that basis, France Article 1188 of the 2016 CC adds that if the mutual intention of the parties cannot be determined, the contract is to be interpreted according to the meaning that a reasonable person placed in the same situation would give to it. The rule is clearly modelled by Article 8(2) CISG and its objective criterion of contract interpretation. ${ }^{119}$

Argentina's new code missed the opportunity to incorporate the 'reasonable person' criterion as an alternative rule for contract interpretation. However, the Argentine code calls for taking into account the nature and object of the contract, the parties' conduct prior and subsequent to its conclusion, and the surrounding circumstances, including the negotiations, in order to reveal the common intention of the contractors. ${ }^{120}$ This rule follows Article 8(3) CISG, and it would have been a proper addition to the new French objective and subjective principles of contract interpretation. Its enactment in France would have reminded the parties and the adjudicator of the relevance that usages and practices have in the subjective understanding of the parties' statements, as well as in the objective understanding of a reasonable man.

The principles of favor negotii, contra proferentem and favor debitoris were maintained in both systems. ${ }^{121}$

Usages and practices also supplement the gaps in the contract in Argentina and France. ${ }^{122}$ The Argentine code now develops the concept, observance requirements and application limits of usages and practices. Those of the place of contract conclusion will be binding by agreement of the parties, or because they are widely known and generally observed in the trade concerned. ${ }^{123}$ The reference to usages and practices at the place of contract conclusion does not prevent the application of different usages and practices, insofar as they are known and observed in the relevant trade or industry. The provision closely follows Article 9 CISG and brings certainty to the parties in a transaction; a similar rule could enhance the application of usages and practices in French law.

118 Argentina Art. 1064 of the 2015 CCCom; France Art. 1189 of the 2016 CC.

119 Méndez-Sierra and Quagilia, 'El Nuevo Derecho De Las Obligaciones T De Los Contratos En Francia', at 5.

120 Argentina Art. 1065 of the 2015 CCCom.

121 See Argentina Arts. 1066, 1068 of the 2015 CCCom; France Arts. 1191, 1190 of the 2016 CC.

122 Argentina Art. 964 of the 2015 CCCom; France Art. 1194 of the 2016 CC.

123 Argentina Art. 964 of the 2015 CCCom. 


\section{H Obligations of the Seller}

In Argentina, a sale is defined as the contract whereby a party agrees to transfer the property of a thing and the other party to pay a price for it in money. ${ }^{124}$ In France a sale is defined as a covenant whereby one party agrees to deliver a thing and the other to pay for it. ${ }^{125}$ The definition of sale in Argentina omits referring to the obligation of delivering the thing, while France overlooks the obligation to transfer the property title. Those obligations are nevertheless implicit in both systems. In France the transfer of property title occurs, unless otherwise agreed, ${ }^{126}$ since the parties agree upon the thing and the price, irrespective of whether or not the goods are delivered and the price paid. ${ }^{127}$ In Argentina, the delivery of the goods is required for the transfer of title according to the traditio doctrine, and, hence, passing of title involves delivery. ${ }^{128}$ The two legal systems remain faithful to their respective approaches on the transfer of title, which also influence the rules on third party property rights. For example, the Argentina traditio system allows the sale of goods by non-owners insofar as sellers are capable of transferring property at the time of delivery. ${ }^{129}$ In France, the sale by non-owners is voidable, and the seller is liable for any damages suffered by the buyer in good faith. ${ }^{130}$ Both approaches are optimal models for law reform, provided the receptor legal system has compatible rules.

Argentina has kept a provision endorsing the passing of property title of the goods through the delivery of conforming documents, such as bills of lading, invoices and other documents representing title. ${ }^{131}$ Argentina also specifies that cost of transport and related expenses up to the point of delivery are to be borne by the seller. ${ }^{132}$ In France, this matter is addressed by case law. Therefore, Argentina presents more identifiable rules in this matter and for the benefit of business people.

In France, the goods must have the characteristics, description and quantity agreed to in the contract. In the absence of an agreement, liability of the seller for lack of conformity of the goods is still based primarily on the statutory warranty of vices cachés: the seller is liable for any hidden defects that render the goods unfit for the use for which they were intended or that impair the particular use for which the buyer has acquired them for. ${ }^{133}$ Accordingly, France has maintained a multi-grounds system of remedies depending on whether the breach concerns a

124 Argentina Art. 1123 of the 2015 CCCom.

125 France Art. 1582 of the 2016 CC.

126 Retention of title clauses are enforceable in France, see Art. 2367 of the 2016 CC.

127 France Art. 1583 of the 2016 CC.

128 Argentina Art. 750 of the 2015 CCCom. On the tradittio doctrine in Latin America see Muñoz, Modern Law of Contracts and Sales in Latin-America, Spain and Portugal at 368, 69.

129 Argentina Art. 1008 of the 2015 CCCom: if the non-owner does not warranty the transfer of title after this date, he is only bound to make its best effort to achieve transfer, and if owing to its fault the title is not transmitted, it shall compensate any losses.

130 France Art. 1599 of the 2016 CC.

131 Argentina Art. 1925 of the 2015 CCCom.

132 Argentina Art. 1138 of the 2015 CCCom.

133 France Art. 1641 of the 2016 CC. 
statutory warranty or an agreed obligation. In case of the statutory warranty of hidden defects, the buyer may request the termination of the contract with restitutory effects or the reduction of price. ${ }^{134}$ No damage claim is allowed under this remedy unless the buyer proves that the seller knew the hidden defects. ${ }^{135}$ The limitation period to bring a claim for hidden defects is two years. ${ }^{136}$ Failure to deliver goods in time and delivery of non-agreed on goods falls into yet another category of breach, which entitles the buyer to claim the avoidance or specific performance of the contract, ${ }^{137}$ plus damages, including lost profits. ${ }^{138}$ The same remedies apply, albeit under a different provision, for the breach of agreed obligations. ${ }^{139}$ The limitation period to bring these types of claims is five years. ${ }^{140}$

Argentina has deviated from this multi-grounds system for assessing conformity of the goods in sale contracts. Article 1156 of the 2015 CCCom closely follows the wording in Article 35(2) CISG, which establishes some default criteria for determining conformity of the goods. Under this approach the goods must be fit for the purposes for which goods of the same description would ordinarily be used or for any particular purpose expressly or impliedly made known to the seller at the time of the conclusion of the contract, except where the circumstances show that the buyer did not rely, or that it was unreasonable for him to rely, on the seller's skill and judgment, or have the qualities of the sample or model under Article 1153 of the 2015 CCCom.

In the authors' view, Argentina's Article 1156 of the 2015 CCCom supersedes the general provisions on hidden defects. In particular, Articles 1051, 1054 and 1055 of the 2015 CCCom, which establish different periods of time for giving notice of defects (sixty days from discovery) and a maximum statutory warranty of six months since delivery or functioning of the goods, should not prevail over Article 1157 of the 2015 CCCom, which requires the buyer to give notice of nonconformity as soon as possible. The unitary approach, which the authors understand is now followed by Argentina regarding the conformity of the goods, has advantages over the cause-oriented approach in France, where remedies for breach of contract are structured in a way that each cause of a disturbance in the performance of the contract triggers a specific remedy. The unitary approach, which is also present in the CISG and the PICC, is easier for jurists and lay-people to understand and apply than is the cause-oriented approach. ${ }^{141}$

134 France Art. 1644 of the 2016 CC.

135 France Art. 1648 of the 2016 CC.

136 Ibid.

137 France Art. 1610 of the 2016 CC.

138 France Art. 1611 of the 2016 CC.

139 France Art. 1217 of the 2016 CC.

140 France Art. 2224 of the 2016 CC.

141 Edgardo Muñoz, 'Understanding the Cisg System of Remedies from the Latin American Domestic Laws', in Ingeborg Schwenzer, Cesear Pereira, and Leandro Tripodi (eds.), CISG and Latin America (The Hague: Eleven Intenational Publishing, 2016) at 96-98. 


\section{Obligations of the Buyer}

The buyer's main obligations are to pay the price and to take delivery of the goods. ${ }^{142}$ The buyer must pay the price at the time and place agreed upon by the parties. Absent an agreement, Argentina and France have kept the rule that the price shall be paid at the time and place of delivery. ${ }^{143}$ This rule departs from the CISG model requiring payment to be made against the handing over of the documents controlling possession of the goods or, at the seller's place of business or where the latter documents are exchanged. ${ }^{144}$ However, the French and Argentinian provisions are still adequate for national trade where controlling documents, such as bills of lading, are not usually involved.

The buyer's obligation to take delivery of the goods was not developed in the new French contract law, while Argentina seized the opportunity to state that the obligation to take delivery consists in doing all the acts that could reasonably be expected of the buyer in order to enable the seller to make delivery and in taking over the goods. ${ }^{145}$ The rule mirrors Article 60 CISG, whose wording helps to clarify the extent of this obligation. A similar provision exists for the obligation to pay the price in Article 54 CISG ${ }^{146}$ Although the latter was designed for international trade, where banking intricacies may affect the full and punctual performance of the payment obligation, a comparable rule would be welcome for national sales in other Latin American jurisdictions.

In order to preserve the right to the remedies for breach of contract, buyers must comply with an implicit duty to examine the goods and give notice of any lack of conformity. ${ }^{147}$ However, France missed the opportunity to develop this duty further in its new contract law; the statutory default provision still requires that any nonconformity be claimed within two years from the moment defects were discovered. ${ }^{148}$ Argentina has complicated the matter with three different time periods. Firstly, a buyer shall give notice of any hidden defects to the seller within sixty days from the moment the defects manifested. ${ }^{149}$ Second, for goods delivered in bundle or under cover that prevent their examination, the buyer shall claim any missing quantity or inadequacy within ten days from delivery. ${ }^{150}$ Third, the sale of goods by sample or for the sale of goods having not been seen by the buyer before delivery, the latter shall give notice to the seller of any lack of conformity without delay. ${ }^{151}$ These approaches are hardly suitable for national or international trade. France and Argentina missed the opportunity to establish a

142 Argentina Arts. 1123 and 1141 of the 2015 CCCom; France Art. 1582 of the 2016 CC.

143 France Art. 1651 of the 2016 CC; Argentina Arts. 874(b) and 1152 of the 2015 CCCom.

144 Arts. 57 and 58 CISG.

145 Argentina Art. 1141(b) of the 2015 CCCom.

146 Art. 54 CISG: "The buyer's obligation to pay the price includes taking such steps and complying with such formalities as may be required under the contract or any laws and regulations to enable payment to be made".

147 See France Art. 1648 of the 2016 CC; Argentina Art. 1054 of the 2015 CCCom.

148 France Art. 1648 of the 2016 CC.

149 Argentina Art. 1054 of the 2015 CCCom.

150 Argentina Art. 1155 of the 2015 CCCom.

151 Argentina Arts. 1153, 1154 y 1157 of the 2015 CCCom. 
flexible period of time for examination of goods and the giving of notice of nonconformity modelled by Articles 38 and 39 CISG. A rule requiring examination within as short a period as is practicable in the circumstances ${ }^{152}$ does no longer require distinguishing between goods that were packaged, transported to the destination or affected by hidden or apparent defects on arrival. The same applies to the buyer's duty to give notice to the seller of the lack of conformity within a reasonable time after the former has discovered it or ought to have discovered it. ${ }^{153}$

\section{J Transfer of Risks}

The parties may agree on the time and place for the transfer of risks over the goods. ${ }^{154}$ Absent an agreement, the default rule in France still establishes that the risk passes from the seller to the buyer at the time of entering into the contract, since the transfer of property also entails transfer of risks over the goods. ${ }^{155}$ The French rule is not appropriate since the goods are often at the seller's possession at the contract conclusion. In light of the seller's duty to protect and care for the goods until delivery, ${ }^{156}$ buyers are usually tempted to claim that sellers did not fulfil such obligations, which creates serious controversies and increases the likelihood of litigation and related costs.

Argentina addresses such common problems of risk transfers with the following default rule: the risk passes to the buyer when the goods are placed at the latter's disposal, the carrier or a third party designated by the buyer. ${ }^{157}$ In that regard, the new Article 1149 of the 2015 Argentinian CCCom endorses the freedom of the parties to agree on the place and method of placing the goods at the buyers' disposal, without prejudice to the buyer's right to inspect the goods at a later time (within ten days). For sales in transit, the provision also recognizes the possibility that delivery (thus risks transfer) takes place by the mere agreement of the parties at the time of assignment and endorsement of documents of transport. The solution reflects Article 68 CISG and the wording of the ICC Incoterms 2020, a welcome development for any sales of goods in transit that may be governed by domestic Argentine law.

152 See Art. 38 CISG.

153 See Art. 39 CISG.

154 France Art. 1196 of the 2016 CC: «Ce transfert peut être différé par la volonté des parties, la nature des choses ou par l'effet de la loi".

155 France Art. 1196 of the 2016 CC. A rule that has influenced many other provisions in the region. For a common provision dictates that any loss of or damage to or improvement in the goods shall be borne by the buyer, despite the fact that the goods had not yet been delivered: Bolivia Art. 600 CC (implied rule); Chile Art. 1820 CC \& Arts. 142, 143(1) Com C; Colombia Art. 1876 CC; Ecuador Art. 1787 CC \& Arts. 187, 188 Com C; Mexico Art. 2014 CC; Paraguay Art. 761 CC; Uruguay Arts. 1682, 1438(I) CC; Spain Arts. 1.182, 1.452 CC; Venezuela Art. 1.161 CC.

156 France Art. 1197 of the 2016 CC.

157 Argentina Art. 1151 of the 2015 CCCom. 
As in their old law, both systems restate that damage of or loss to the goods caused by hidden defects existing prior to the transfer of risks are to be borne by the seller. ${ }^{158}$

\section{K Remedies for Breach of Contract}

\section{Right to Suspend Performance}

Parties must fulfil their obligations in the manner and time agreed to. The default rule in both systems is that, in bilateral contracts, parties should fulfil their obligations simultaneously. ${ }^{159}$ However, a party may withhold performance of its obligations under the doctrine of exceptio non adimpleti contractus. The possibility to stop performance was already enunciated in Argentina's statutory law, ${ }^{160}$ but the provision in the new Argentine CCCom has a clearer wording that mirrors Article 7.1.3 PICC: either party may withhold performance until the other party tenders its performance. ${ }^{161}$ Also, the new contract law has considerably narrowed down the possibility to suspend payment by the buyer until the examination of the goods occurs (unless the payment method agreed is not compatible with such possibility); ${ }^{162}$ the old law allowed the buyer to refuse payment if the seller did not exactly deliver what was agreed upon or if the seller intended to deliver the goods in instalments, of different quality or without accessories. ${ }^{163}$ Furthermore, the Argentine 2015 CCCom now sets a high standard of prejudice and further requirements to withhold performance, influenced by Article 71 CISG: a party may suspend performance only if it is affected by a great risk of damage, owing to the other party's serious deficiency in its ability to perform or in its creditworthiness; and suspension should be lifted if the other party provides adequate assurance that it will perform. ${ }^{164}$

France's Civil Code now states the right to withhold performance, which was recognized only in case law previously. ${ }^{165}$ French law also requires that the possibility of failure by a party has sufficiently grave consequences. ${ }^{166}$ In this regard, Argentina and France differ from Article 71(1) CISG, which points to risks that "the other party will not perform a substantial part of its obligations". The evidence of serious damage or consequences under the Argentine and French codes may make more difficult to reach the standard of evidence for suspension. In addition, the French law does not establish the indicia of risk of lack of performance on which a party may rely. But Article 1613 of the 2016 French CC

158 France Art. 1147(2) of the 2016 CC.

159 Argentina Art. 1031 of the 2015 CCCom.

160 See former Argentina Arts. 1201 and 1426 of the CC.

161 Argentina Art. 1031 of the 2015 CCCom.

162 Argentina Art. 1152 of the 2015 CCCom.

163 See former Argentina Art. 1426 of the CC.

164 Argentina Art. 1031 of the 2015 CCCom.

165 Chénedé, Le Nouveau Droit Des Obligations Et Des Contrats: Consolidations - Innovations Perspective at 180, para. 28.51; Bénabent, Droit Des Obligations at 298, para. 367.

166 France Arts. 1220 and 1219 of the 2016 CC. 
on sales may be taken as guidance applicable to all parties. ${ }^{167}$ On the other hand, French law requires the party who exercises the right of withholding performance to give notice of the suspension to the other party as soon as possible, ${ }^{168}$ a welcome addition that follows Article 71(3) CISG and that enhances legal certainty for the other party. Argentina does not state the same notice requirement; thus, France's law may be considered better in that respect.

\section{Specific Performance}

Both legal systems affirm the central place of specific performance as a remedy for breach of contract. ${ }^{169}$ This remedy was imperfectly stated in the French 1804 CC since the old Article 1142 emphasized damages to the exclusion of other remedies. However, specific performance was also a choice upheld by the Cour de Cassation previous case law. ${ }^{170}$ A notable addition is the express deviation from the principle of pacta sunt servanda in some circumstances. Article 1221 of the French 2016 CC states that the remedy of specific performance should not be ordered where there is a manifest lack of proportion between its cost to the promisor and the benefit to the promisee. The wording was added to clarify the consequences of the doctrine of hardship, which constitutes another significant innovation in French law (see later in this section).

\section{Damages}

Argentina now addresses damage liability arising out of breach of contract and tort under the same rules scheme. ${ }^{171}$ France still distinguishes the rules applicable to each type of liability. ${ }^{172}$ Both systems endorse the principle of full compensation: the injured party is entitled to damages, including lost profits, that are the consequence of the breach. ${ }^{173}$ In addition, what is a duty derived from the principle of good faith in French law ${ }^{174}$ has been now converted in the statutory duty to mitigate damages under Argentine law. ${ }^{175}$ The rule in Article 1710 of the 2015 CCCom also states the right to recover the expenses incurred in mitigating losses under the unjust enrichment rules.

167 France Art. 1613 of the 2016 CC: the seller will not be liable for failure to deliver if after the conclusion of the sales contract the buyer becomes insolvent or bankrupt, so that the seller is in imminent danger of losing the price; unless the buyer gives to the seller securities that the former will pay at the end.

168 France Arts. 1217 and 1220 of the 2016 CC.

169 Argentina Art. 777 of the 2015 CCCom; France Art. 1221 of the 2016 CC.

170 Chénedé, Le Nouveau Droit Des Obligations Et Des Contrats: Consolidations - Innovations Perspective at 183, para. 28.91.

171 Sebastián Picasso, 'Art. 1737', in Marisa Herrera and Gustavo \& Sebastián Picasso Caramelo (eds.), Código Civil Y Comercial De La Nación Comentado (IV; Buenos Aires: Ministerio de Justicia y Derechos Humanos, 2015) at 417; Argentina Arts. 1737 et seq. of the 2015 CCCom.

172 See France Art. 1231(1-7) and compare with Arts. 1240 et seq. of the 2016 CC; Bénabent, Droit Des Obligations at 318, para. 404.

173 France Art. 1231-3 of the 2016 CC; Argentina Art. 1739 of the 2015 CCCom.

174 Bénabent, Droit Des Obligations at 331-32, para. 426: "La jurisprudence francaise, san l'aide de ce principe [mitigation / dommage atténuable], parvient parfois à consacrer la même idée, souvent au moyen de la notion de bonne foi. Mais elle refuse d'en faire un principe."

175 See Argentina Art. 1710 of the 2015 CCCom. 


\section{Exemption}

The new contract laws of Argentina and France have each developed the grounds for exemption for breach of contract. ${ }^{176}$ On the one hand, the very French force majeure doctrine has been defined for the first time in the code and influenced by Article 79 CISG:177 an impediment beyond the obligor's control that could not be reasonably expected at the time of the conclusion of the contract, whose effects could not have been avoided or overcome by appropriate measures. ${ }^{178}$ Argentina follows the same requirements through the definition of force majeure, which in turn fits into the larger new concept of impossibility. ${ }^{179}$

On the other hand, Argentina has incorporated frustration of the final cause of the contract as a ground for avoidance. ${ }^{180}$ As under the doctrine of frustration in Anglo-American Law, ${ }^{181}$ the contract is rendered useless by the extraordinary change of circumstances, which existed at the time of formation, unrelated to the parties and beyond the risks assumed by the obligor. ${ }^{182}$ For the first time, France allows the exemption in favour of a party to a contract in case of a change of

176 It is important to note that economically speaking, according to Posner and Rosenfield: "The discharge question arises only in those cases where the contract does assign the risk in question and the event giving rise to the discharge claim was not avoidable by any cost-justified precautions. When these threshold conditions have been satisfied, economic analysis suggests that the loss should be placed on the party who is the superior (that is, lower-cost) risk bearer. To determine which party is the superior risk bearer three factors relevant-knowledge of the magnitude of the loss, knowledge of the probability that it will occur, and (other) costs of self- or market-insurance"; see Richard Posner and Andrew M. Rosendfiled, 'Impossibility and Related Doctrines in Contract Law: An Economic Analysis', The Journal of Legal Studies, 6/1 (1997) at 117. See also, Cooter and Ulen, Law \& Economics at 287.

177 Chénedé, Le Nouveau Droit Des Obligations Et Des Contrats: Consolidations - Innovations Perspective at 176, para. 28.21. "Évoquée à l'ancien article 1148, la force majeure n'avait pas été définie par les rédacteurs de Code Civile."

178 France Art. 1218 of the 2016 CC; Art. 7.1.7(1) PICC; Art. 8:808(1) PECL; Art. III - 3:104(1) DCFR are practically identical to Art. 79(1) CISG. The same holds true for the ICC Force Majeure Clause. However, the latter gives a list of events that may amount to an impediment.

179 Argentina Arts. 1730, 1731 and 1732 of the 2015 CCCom.

180 Argentina Art. 1090 of the 2015 CCCom; Gustavo Caramelo, 'Art. 1090', in Marisa Herrera and Gustavo \& Sebastián Picasso Caramelo (eds.), Código Civil Y Comercial De La Nación Comentado (III; Buenos Aires: Ministerio de Justicia y Derechos Humanos, 2015c) at 483.

181 Argentina Art. 1090 of the 2015 CCCom; United States $\S 2-615$ UCC. The Restatement Second, Contracts, reiterates this position: see American Law Institute Restatement on the Law of Contracts (2nd edn., St Paul: American Law Institute Publishers, 1981) § 261; the seminal case on this rule is Transatlantic Financing Corporation, Appellant, v. United States of America, Appellee, 363 F.2d 312 (D.C. Cir. 1966) cited in Alissa Palumbo, Modern Law of Sales in the United States, ed. Ingeborg Schwenzer (International Commerce and Arbitration, 17; The Hague: Eleven International Publishing, 2015) at 165, 66. Also see Larry Dimatteo, International Contracting: Law and Practice (3rd edn.; The Netherlands: Wolters Kluwer, 2013) at 264, para. 7.23; Schwenzer, Hachem, and Kee, Global Sales and Contract Law at 652, para. 45.13; Christoph Brunner, Force Majeure and Hardship under General Contract Principles: Exemption for NonPerformance in International Arbitration (International Arbitration Law Library, 18; The Hague: Kluwer Law International, 2008) at 410.

182 Argentina Art. 1090 of the 2015 CCCom; Caramelo, 'Art. 1090', at 483. 
circumstances, also known as hardship. ${ }^{183}$ Until then, French law was not favourable to the concept of hardship; the theory of imprévision applied to administrative contracts only. ${ }^{184}$ Now, under Article 1195 of the 2016 French CC, if a change of circumstances that was unforeseeable at the time of the conclusion of the contract renders performance excessively onerous for a party who had not accepted the risk of such a change, that party may ask the other contracting party to renegotiate the contract. In case of refusal or the failure of renegotiations, the parties may agree to terminate the contract from the date and on the conditions that they determine or, by a common agreement, ask a court to adapt the contract. In the absence of an agreement within a reasonable time, the court may, at the request of a party, revise the contract or put an end to it, from a date and subject to such conditions as it shall determine. Argentina already contemplated the ground of hardship for exemption. ${ }^{185}$ The wording of the new Article 1091 closely follows the previous notion and also the French understanding of imprévision ${ }^{186}$ However, there are two changes or differences worth noting. The new Argentine CCCom now entitles the disadvantaged party to request the contract adaptation to a third party (court or arbitral tribunal) or to avoid the contract unilaterally by declaration, in addition to the former possibility to claim the avoidance of the contract by the adjudicator. ${ }^{187}$

As submitted in a different contribution, ${ }^{188}$ the better remedy, i.e. solution, in a hardship scenario may be the unilateral declaration of avoidance by obligee contemplated in Argentina. The duty to renegotiate, although present in several legal systems, ${ }^{189}$ is neither necessary nor desirable. A duty to renegotiate should not be imposed on the parties, in particular, if there are no legal consequences in case of breach of such duty. ${ }^{190}$ Hardship scenarios and the duty to mitigate damages already offer strong factual incentives to both parties to renegotiate voluntarily. Furthermore, procedural incentives for negotiation such as multi-tier dispute resolution clauses applying to all kinds of conflicts are preferable to a duty to renegotiate rooted in substantive law. ${ }^{191}$

183 Chénedé, Le Nouveau Droit Des Obligations Et Des Contrats: Consolidations - Innovations Perspective at 142, para. 25.51; Bénabent, Droit Des Obligations at 253, para. 309.

184 Bénabent, Droit Des Obligations at 253, para. 309; Jean-Christophe Roda, 'Réflexions Pratiques Sur L'imprévision', in Mathias Latina (ed.), La Réforme Du Droit Des Contrats En Pratique (France: Dalloz, 2017) at 70.

185 See old Argentina Art. 1198 of the CC.

186 Argentina Art. 1091 of the 2015 CCCom.

187 Argentina Art. 1091 of the 2015 CCCom, and Gustavo Caramelo, 'Art. 1091', in Marisa Herrera and Gustavo \& Sebastián Picasso Caramelo (eds.), Código Civil Y Comercial De La Nación Comentado (III; Buenos Aires: Ministerio de Justicia y Derechos Humanos, 2015d) at 486.

188 See Ingeborg Schwenzer and Edgardo Muñoz, 'Duty to Renegotiate and Contract Adaptation in Case of Hardship', Uniform Law Review, 24/1 (2019) at 149-74.

189 Art. 6:111 PECL; Art. 6.2.3 UNIDROIT PICC; Section III-1:110 DCFR; Art. 84(1) PLACL; Armenia Art. 467 CC; Azerbaijan Art. 422 CC; France Art. 1195 CC; Lithuania Art. 5.204 CC; Russia Art. 451 CC; Ukraine Art. 652 CC.

190 Schwenzer and Muñoz, 'Duty to Renegotiate and Contract Adaptation in Case of Hardship', at 161.

191 Ibid., at 162. 
Similarly, the remedy of contract adaptation by a court or arbitral tribunal is neither necessary nor desirable. This rule eliminates the parties' ability to find a bilateral solution to their problem. In addition, a decision adapting the contract by an adjudication body often arrives late. ${ }^{192}$ Prompt solutions are essential, and the main adjudicatory systems in place today do not serve this purpose. In the same way, the remedy of avoidance by a court or arbitral tribunal is not optimal. It contradicts the international modern solution of avoidance by declaration by the aggrieved party, which has a clear advantage of predictability and low efficiency cost over the mechanisms of ipso facto avoidance or the court declaration of avoidance. ${ }^{193}$

\section{$V$ Avoidance}

The remedy of contract avoidance has also experienced some welcome developments in both systems. The French Code now endorses the avoidance of the contract by the sole effect of the terms of any agreed clause résolutoire and without condition of gravity and from the notice of avoidance by the obligee; ${ }^{194}$ the judge may no longer intervene to determine its justification. ${ }^{195}$ Argentina already recognized the same effects for similar cláusulas resolutorias. ${ }^{196}$

The default new rule in France and Argentina also recognizes the avoidance of the contract by a party declaration (departing from the old avoidance declaration by court). ${ }^{197}$ The requirements for avoidance have also been systematically and clearly integrated into the codes with concepts influenced by the fundamental breach and nachfrist notions in Article 25, 49(1)(b), 63/64(1)(b) CISG. For instance, France Article 1226 CC states that an obligee must previously have put the debtor in default on notice to perform his undertaking within a reasonable time in order to avoid the contract by declaration. Argentina's Article 1088 CCCom contemplates the avoidance of the contract after the obligor has failed to comply within the period of time fixed by the obligee, which cannot be less than fifteen days. ${ }^{198}$ The French Code clarifies that the additional period of time for performance is not necessary in case of urgency, without providing indicia of this meaning, while in Argentina the same applies in case performance in time was of the essence. ${ }^{199}$ It will be a matter of contract interpretation to decide whether the performance of certain obligations on time was of the essence. In any case, the right to avoid the contract requires reaching a high

192 Ibid., at 165.

193 Ibid., at 167.

194 France Art. 1124 in conjunction with Art. 1226 of the 2016 CC, compared with the old Art. 1184 of the CC.

195 Bénabent, Droit Des Obligations at 313, para. 97.

196 Argentina Art. 1086 of the 2015 CCCom, compared with the old 1204(3) of the CC.

197 Argentina Art. 1088(c) of the 2015 CCCom: "la resolución total o parcial del contrato se produce cuando el acreedor la declara y la comunicación es recibida por la otra parte"; France Art. 1226 the 2016 CC; Chénedé, Le Nouveau Droit Des Obligations Et Des Contrats: Consolidations - Innovations Perspective at 197, para. 28.71.

198 Argentina Art. 1088(c) of the 2015 CCCom.

199 Argentina Art. 1088(c) of the 2015 CCCom; France Art. 1226 of the 2016 CC. 
standard of breach: esencial in Spanish or grave in French. ${ }^{200}$ Regrettably, the French Code does not provide a definition or any criteria to determine what may constitute a sufficiently grave breach. One scholar considers that the type of breach includes cases in which the essential satisfaction expected by one party is annihilated or compromised by the other party's failure. ${ }^{201}$ This understanding assimilates the concept of grave breach in France's Article 1084 CC to the notion of fundamental breach in Article 25 of the CISG. But the CISG's influence is clearer in Argentina, where an 'essential breach' is defined as one that substantially deprives the other party of what it is entitled to expect under the contract. $^{202}$

\section{Conclusion}

The new contract law both in France and Argentina constitutes models for future reform in Latin American jurisdictions. Both legal systems, from the civil law family, have adopted new rules that are visibly influenced by the uniform law found in the CISG and the PICC. This article compared the solutions adopted in Argentina and France for important contract law matters. From the perspective of the functional method of comparative law (through tertium comparationis exercises and the better law analysis), we were able to highlight the most obvious similarities and differences in both models. We also concluded that, on certain issues, Argentine law offers more optimal or effective rules to achieve the desired function, while French law achieves better results in some other areas. Together, these two contractual models provide a range of complementary solutions to each other. In other words, the conclusions reached in each of the sections of this contribution provide the best rules or solutions to address the problems in question. In this way, the reader can identify, in our opinion, the most appropriate model provision from one or another system for modern contractual law reform.

200 Argentina Art. 1084 of the 2015 CCCom; France Art. 1224 of the 2016 CC.

201 Bénabent, Droit des Obligations at 310, para. 90.

202 Argentina Art. 1084(c) of the 2015 CCCom. A breach is also fundamental when it is intentional, the obligee has announced it will not perform in advance or when it is so qualified by the contract. 